\title{
Conclusion: Popular Criminology Revisited
}

\section{Dimitris Akrivos}

Canterbury Christ Church University

\section{Alexandros K. Antoniou}

University of Essex

Popular culture is not just the music playing on the radio as we wake up, the clothes we wear, the newspapers, magazines or crime novels we read, the football match we watch on TV, or the information popping up on our social media news feeds. Popular culture is all and many more of these things we interact with casually, often without even thinking about it, on a daily basis and without which our lives would be completely different. Popular cultural portrayals of crime, justice and deviance provide discourses which constitute a key point of reference for the public to make sense of these issues; what Rafter (2007) has called 'popular criminology'. This popular criminology is not (neither does it aspire to be) as theoretically grounded or empirically evidenced as academic criminology but can actually have a much greater cultural impact than the latter, as it goes beyond the academic community and has the potential to reach a far higher number of people (Kohm and Greenhill, 2011; Rafter and Brown, 2011).

It has been more than a decade after Rafter's call for the development of a popular criminology and the growing cultural criminology movement has covered a lot of ground in the study of cultural representations of rule-breaking and transgression since (see, for instance, Ferrell, 1999; Ferrell and Websdale, 1999; Ferrell et al., 2004; Presdee, 2000; Ferrell, Hayward and Young, 2015). In a fast-paced post-modern world with a continuously expanding and rapidly changing popular culture, the discussion on the interaction between academic and popular criminology is nowadays more topical than ever. It has been argued that academic and popular discourses of crime and deviance are not mutually exclusive, but co-exist in a symbiotic relationship with each other (Rafter, 2007). Criminal and deviant behaviours do not 
take place in a vacuum but acquire meaning based on the broader socio-cultural context within which they occur.

Despite all the important steps that have been made towards bringing academic and popular criminology together, there is still a lot of room for the links between the two to be strengthened and further extended. This is precisely what we have attempted to do in this book. Keeping up with all the different facets of contemporary popular culture and the plethora of texts produced and disseminated on a daily basis can be a real challenge for academic researchers in the field. The chapters of this volume explored some of the most important aspects of popular culture, looking at contemporary case studies, discussing topical issues and exploring how real-life anxieties and dominant ideologies are often transferred to or challenged in popular texts.

The contributors of this collection have taken readers on a journey as diverse and fascinating as modern-day popular culture itself: we have travelled through post-9/11 America, welfarist Denmark and Sweden, England, Austria, Australia and the strange land of cyberspace, exploring issues of terrorism, surveillance, Islamophobia, gender and sexual violence, sports alongside fictional detectives, graffiti artists, outlaw bikers and true crime memoirists. By doing so, we have advanced the academic scholarship in the respective research areas and simultaneously raised important questions and opened up avenues for future criminological inquiry. Particularly, the chapters included in this book have provided a paradigm for the study of other popular cultural artefacts not analysed in this book. They have also laid the groundwork for a more informed future discussion on audiences' engagement with such artefacts.

When criminology goes to the movies, Rafter and Brown (2011) aptly point out, or by the same token when it watches TV, plays video games or otherwise immerses itself in any other aspect of popular culture, it sees itself in a new light. In April 2018, the news that crime thriller and detective novels' sales in the UK nowadays outsell all other fiction provided yet 
another confirmation of the great public appeal of the genre; an appeal which, in the era of media convergence, is not limited to novels per se but also spills over into other cultural industries adapting these for the television, cinema, theatre and so on (Hannah, 2018). As today's crime narratives multiply in numbers and maximise revenues and profits, studying the messages communicated through them, along with the respective processes of production and consumption, is vital to the understanding of crime as a cultural phenomenon.

\section{References}

Ferrell, J., 1999. Cultural Criminology. Annual Review of Sociology, 25(1), pp. 395-418.

Ferrell, J., Hayward, K., Morrison, W. and Presdee, M. eds., 2004. Cultural Criminology Unleashed. London: GlassHouse Press.

Ferrell, J., Hayward, K. and Young, J. 2015. Cultural Criminology: An Invitation. $2^{\text {nd }}$ ed. London: Sage.

Ferrell, J. and Websdale, N. eds., 1999. Making Trouble: Cultural Constructions of Crime, Deviance, and Control. Hawthorne, NY: Aldine de Gruyter.

Hannah, S., 2018. It's no mystery that crime is the biggest-selling genre in books. The Guardian, [online] 12 April. Available at: <https://www.theguardian.com/books/booksblog/2018/apr/12/mystery-crime-fictionbestselling-book-genre-sophie-hannah> [Accessed 24 May 2018].

Kohm, S. and Greenhill, P., 2011. Pedophile Crime Films as Popular Criminology: A Problem of Justice? Theoretical Criminology, 15(2), pp. 195-215.

Presdee, M. 2000. Cultural Criminology and the Carnival of Crime. London: Routledge.

Rafter, N., 2007. Crime, Film and Criminology. Theoretical Criminology, 11(3), pp. 403-420. 
Rafter, N. and Brown, M., 2011. Criminology Goes to the Movies. New York: New York University Press. 